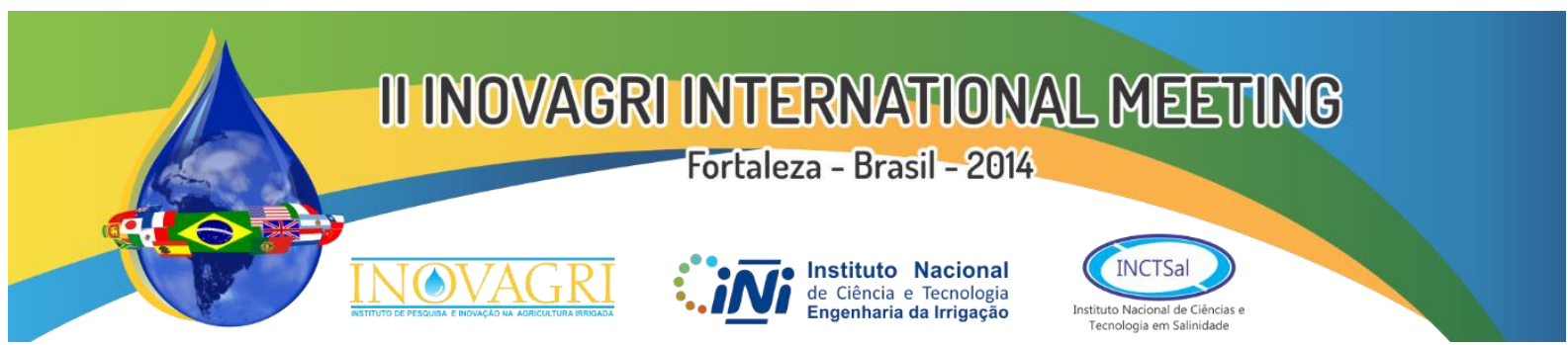

http://dx.doi.org/10.12702/ii.inovagri.2014-a606

\title{
ROOT GROWTH, NITROGEN AND PHOSPHORUS UPTAKE AND USE EFFICIENCY IN TROPICAL LEGUME CROPS AS INFLUENCED BY PHOSPHORUS FERTILIZATION
}

\author{
N. K. Fageria ${ }^{1}$, H. R. Gheyi ${ }^{2}$ M. C. S. Carvalho ${ }^{1}$ and A. Moreira ${ }^{3}$
}

\begin{abstract}
Root is an important organ which supplies water and nutrients to growing plants. Data related to root growth and nutrient uptake by tropical legume cover crops are limited. The objective of this study was to evaluate root growth of tropical legume cover crops and nitrogen and phosphorus uptake and use efficiency under different phosphorus (P) levels. The P levels used were 0 (low), 100 (medium) and 200 (high) $\mathrm{mg} \mathrm{kg}^{-1}$ of soil and 5 cover crops were evaluated. Root dry weight, maximum root length, specific root length were significantly influenced by $\mathrm{P}$ and cover crop treatments. Maximum values of these root growth parameters were achieved with the addition of 100 $\mathrm{mg} \mathrm{P} \mathrm{kg}{ }^{-1}$ soil. The $\mathrm{P} \mathrm{x}$ cover crops interaction for all the macro and micronutrients, except $\mathrm{Mn}$ was significant, indicating variation in uptake pattern of these nutrients by cover crops with the variation in $\mathrm{P}$ rates. Cover crops which produced higher root dry weight also accumulated higher amount of $\mathrm{N}$ and $\mathrm{P}$ compared to cover crops which produced lower root dry weight. Higher uptake of $\mathrm{N}$ compared to other nutrients by cover crops indicated that use of cover crops in the cropping systems can reduce loss of $\mathrm{NO}_{3}{ }^{-}$from soil-plant systems.
\end{abstract}

Keywords: Root dry weight, root length, root-shoot ratio, shoots dry weight

\section{CRESCIMENTO DAS RAÍZES, ABSORÇÃO E EFICIÊNCIA DE UTILIZAÇÃO DE NITROGÊNIO E FÓSFORO EM CULTURAS LEGUMINOSAS TROPICAIS SOB FERTILIZAÇÃO FÓSFORO}

RESUMO: Raiz é um órgão importante que fornece água e nutrientes para as plantas que crescem. Os dados relativos ao crescimento radicular e na absorção de nutrientes pelas culturas leguminosas tropicais de cobertura são limitadas. O objetivo deste estudo foi avaliar o crescimento radicular de plantas leguminosas tropicais de cobertura, absorção e eficiência de utilização de nitrogênio e fósforo sob difererentes níveis de fósforo. Os níveis de P utilizadas foram de 0 (baixo), 100 (médio) e 200 (alto) $\mathrm{mg} \mathrm{kg}^{-1}$ de solo e cinco plantas de cobertura foram avaliados. Peso seco, comprimento máximo, comprimento específica de raiz foram significativamente influenciados pelos $\mathrm{P}$ e tratamentos de culturas de cobertura. Os valores máximos desses parâmetros de crescimento da raiz foram obtidos com a adição de $100 \mathrm{mg} \mathrm{P} \mathrm{kg}^{-1}$ de solo. A interação culturas de cobertura x P para todos os macro e micronutrientes, exceto $\mathrm{Mn}$ foi significativa, indicando variação no padrão de absorção destes nutrientes pelas culturas de cobertura com a doses de P. Cultura de culturas que apresentaram maior peso seco de raiz também acumularam maior quantidade de $\mathrm{N}$ e $\mathrm{P}$ em comparação com culturas de cobertura que produziram massa seca de raiz mais baixa. Absorção maior de $\mathrm{N}$ em comparação com outros nutrientes pelas culturas de cobertura indica que o uso de plantas de cobertura nos sistemas de cultivo pode reduzir perda de $\mathrm{NO}_{3}{ }^{-}$nos sistemas solo-planta.

Palavras chave: Peso seco de raiz, cumprimento radicular, relação raiz-parte aérea, peso seco do caule

\footnotetext{
${ }^{1}$ National Rice and Bean Research Center of EMBRAPA (Empresa Brasileira de Pesquisa Agropecuária), Caixa Postal 179, Santo Antônio de Goiás, GO, CEP 75375-000, Brazil and;

${ }^{2}$ Visiting Professor, Federal University of Reconcavo of Bahia, 44380000 Cruz das Almas, BA. Brazil.

${ }^{3}$ National Soybean Research Center, Londrina, Parana, Brazil.
}

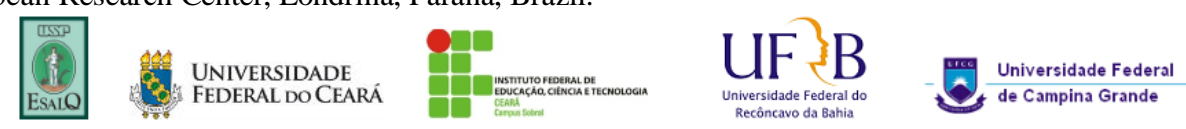




\section{INTRODUCTION}

Root is an important organ which supplies water and nutrients to growing plants. In addition, root also provides mechanical support to plants. Root contributes significantly in improving organic matter of soil and consequently improving soil quality. It also supplies certain hormones to plants which are important for many physiological and biochemical reactions in plants. Root growth is influence by many environmental factors like water content of the soil, temperature, soil physical, chemical and biological properties (Fageria, 2009).

Growing cover crops in the cropping systems is an important strategy in improving soil quality and consequently crop yields (Fageria et al. 2005; Fageria, 2007; Baligar and Fageria, 2007). The benefits of growing cover crops in rotation with annual crops are known since ancient times. Cover crops add organic matter in the soil, control erosion, suppress weeds, conserve soil moisture and control diseases (Fageria et al. 2005). In addition, cover crops uptake nutrients which may be lost through leaching in the soil profile and may contaminate ground water. Hence, cover crops can help in reducing environmental pollution.

Phosphorus deficiency is one of the most growth limiting factors for crops grown on tropical Oxisols (Fageria and Baligar, 2008). The phosphorus deficiency in tropical Oxisols is related to their natural low level of this element as well as high immobilization capacity due to presence of iron and aluminum oxides. Data are limited on influence of phosphorus on root growth and nutrient uptake by tropical legume cover crops. The objective of this study was to evaluate influence of phosphorus fertilization on root growth and nutrient uptake and us efficiency in important tropical legume cover crops.

\section{MATERIALS AND METHODS}

A green house experiment was conducted at the National Rice and Bean Research Center of EMBRAPA, Santo Antônio de Goiás, Brazil to evaluate root growth and nutrient uptake and use efficiency by five tropical cover crops. The soil used in the experiment was Oxisol with following chemical and physical properties before imposing acidity treatments: $\mathrm{pH}$ in $\mathrm{H}_{2} \mathrm{O} 5.8, \mathrm{Ca} 1.17 \mathrm{cmol}_{\mathrm{c}} \mathrm{kg}^{-}$ 1, Mg 0.6 cmol $_{\mathrm{c}} \mathrm{kg}^{-1}$, Al $0.1 \mathrm{cmol}_{\mathrm{c}} \mathrm{kg}^{-1}$, P $0.9 \mathrm{mg} \mathrm{kg}^{-1}, \mathrm{~K} 33 \mathrm{mg} \mathrm{kg}^{-1}$, Cu $1.2 \mathrm{mg} \mathrm{kg}^{-1}, \mathrm{Zn} 1.1 \mathrm{mg} \mathrm{kg}^{-1}$, Fe $35 \mathrm{mg} \mathrm{kg}^{-1}$, Mn $8 \mathrm{mg} \mathrm{kg}^{-1}$ and organic matter $20 \mathrm{~g} \mathrm{~kg}^{-1}$, clay $569 \mathrm{~g} \mathrm{~kg}^{-1}$, Silt $140 \mathrm{~g} \mathrm{~kg}^{-1}$ and sand 291 $\mathrm{g} \mathrm{kg}^{-1}$. Soil analysis methodology used is described in manual of soil analysis (EMBRAPA, 1997).

The experiment was conducted in plastic pots with $9 \mathrm{~kg}$ soil in each pot. Cover crops evaluated were sunnhemp (Crotalaria juncea L.), pigeonpea (Cajanaus cajan L. Millspaugh), lablab (Dolichos lablab L.), gray mucuna bean (Mucuna cinereum L.), and white jack bean (Canavalia ensiformais $\mathrm{L}$. DC.). The $\mathrm{P}$ levels used were $0 \mathrm{mg} \mathrm{kg}{ }^{-1}$ (low), $100 \mathrm{mg} \mathrm{kg}^{-1}$ (medium), and $200 \mathrm{mg} \mathrm{kg}^{-1}$ (high), applied as triple super phosphate. Experimental design was split plot, $\mathrm{P}$ levels were in the main plot and cover crops in the sub-plot. Treatments were replicated three times. Each pot received $10 \mathrm{~g}$ dolomitic lime 4 weeks before sowing the cover crops and pots were subjected to dry and wet cycling. The liming material used was having $32.9 \% \mathrm{CaO}, 14.0 \% \mathrm{MgO}$ and neutralizing power of $85 \%$. At the time of sowing basal fertilizers rates used were $200 \mathrm{mg} \mathrm{N} \mathrm{kg}^{-1}$ of soil, $200 \mathrm{mg} \mathrm{P} \mathrm{kg}^{-1}$ o soil and $200 \mathrm{mg} \mathrm{K} \mathrm{kg} \mathrm{g}^{-1}$ of soil. Nitrogen was applied as urea and $\mathrm{K}$ was applied as potassium chloride. After germination, 4 plants were maintained in each pot. Plants were harvested at an age of 35 days after sowing. Root from each pot was removed manually and maximum root length was measured. Harvested material was washed in distilled water several times and was dried in an oven at $70{ }^{\circ} \mathrm{C}$ to a constant weight. Dried root material was grounded and analyzed for $\mathrm{N}$ and P according to methodology of Silva (1999).

Nutrient use efficiency $\left(\mathrm{mg} \mathrm{mg}^{-1}\right.$ or $\left.\mathrm{mg}_{\mu} \mathrm{g}^{-1}\right)=\frac{\text { Root dry weight in } \mathrm{mg}}{\text { Nutrient uptake in } \mathrm{mg} \text { or } \mu \mathrm{g}}$

Where uptake of macronutrients was in mg and micronutrients was in $\mu \mathrm{g}$.

Data were analyzed by analysis of variance to evaluate treatment effects and means were compared by Turkeys test at $5 \%$ probability level. 


\section{RESULTS AND DISCUSSION}

\section{Root Growth}

Phosphorus $\mathrm{X}$ cover crop interactions for root dry weight and maximum root length were significant (Tables 1 and 2), indicating differential performance of cover crops tested at different $\mathrm{P}$ levels, influences selection and recommendation of cover crops. Root dry weight varied from 0.13 to $0.77 \mathrm{~g} \mathrm{plant}^{-1}$ at low P level, with an average value of $0.35 \mathrm{~g} \mathrm{plant}^{-1}$. Similarly, at medium P level, root dry weight varied from 0.51 to $1.14 \mathrm{~g} \mathrm{plant}^{-1}$, with an average value of $0.89 \mathrm{~g} \mathrm{plant}^{-1}$. At high P level, root dry weight varied from 0.13 to $1.42 \mathrm{~g} \mathrm{plant}^{-1}$, with an average value of $0.82 \mathrm{~g} \mathrm{plant}^{-1}$. Overall, significant increase in root dry weight with the addition of $\mathrm{P}$ up to $100 \mathrm{mg} \mathrm{P} \mathrm{kg}^{-1}$ soil. Increase in root weight of crop plants with the addition of $\mathrm{P}$ in Brazilian Oxisol is reported by Fageria (2009).

Maximum root growth varied from $19.67 \mathrm{~cm}$ to $36.00 \mathrm{~cm}$, with an average value of $27.40 \mathrm{~cm}$ at low P level. At medium P levels, the maximum root length varied from 24.50 to $50.33 \mathrm{~cm}$, with an average value of $35.17 \mathrm{~cm}$. Similarly, at high P level, the maximum root length varied from 22.00 to $52.33 \mathrm{~cm}$, with an average value of $35.47 \mathrm{~cm}$. Overall, root length increase was $28 \%$ with the addition of $100 \mathrm{mg} \mathrm{P} \mathrm{kg}^{-1}$ soil compared with control treatment. Improvement in root length with the addition of $\mathrm{P}$ in crop plants in Brazilian Oxisols is reported by Fageria (2009) and Fageria and Moreira (2011).

\section{Uptake of Nitrogen and Phosphorus}

Uptake of $\mathrm{N}$ and $\mathrm{P}$ in the roots of cover crops was significantly influenced by $\mathrm{P}$, cover crops and P X cover crop interaction (Table 3). The significant P X cover crops interaction indicates different uptake pattern of $\mathrm{N}$ and $\mathrm{P}$ by cover crops at different $\mathrm{P}$ levels. Nitrogen uptake significantly improved with the addition of $\mathrm{P}$, however there was difference in $\mathrm{N}$ uptake among cover crops. At medium and high $\mathrm{P}$ level, $\mathrm{N}$ uptake in the roots of cover crops was almost double compared to control treatment. Positive influence of P on the uptake of N in crop plants is reported by Fageria (2009). Fageria (2009) also reported that the positive influence of $\mathrm{P}$ on $\mathrm{N}$ uptake may be related to improvement in growth and yield of crop plants with the $\mathrm{P}$ fertilization.

Uptake of $\mathrm{P}$ increased with the increase in $\mathrm{P}$ levels in the growth medium. At low $\mathrm{P}$ level, $\mathrm{P}$ uptake varied from 0.11 to $0.44 \mathrm{mg} \mathrm{plant}^{-1}$, with an average value of $0.27 \mathrm{mg} \mathrm{plant}^{-1}$. At medium and high $\mathrm{P}$ levels, $\mathrm{P}$ uptake values varied from 0.42 to $1.66 \mathrm{mg} \mathrm{plant}^{-1}$ and 0.18 to $3.33 \mathrm{mg} \mathrm{plant}^{-1}$, respectively. Over all, P uptake increased 4 and 6 fold with the addition of 100 and $200 \mathrm{mg} \mathrm{P} \mathrm{kg}^{-1}$ soil, respectively compared to $0 \mathrm{mg} \mathrm{P} \mathrm{kg}{ }^{-1}$ soil. However, there were significant differences among cover crop species in P uptake. A variety of root property like length, dry weight, density and root hairs might have caused variation in P uptake among the cover crop species (Hinsinger, 1998; Gahoonia and Nielsen , 2004). In addition, increased P activity in the rhizosphere soil, increased the hydrolysis of soil phosphate esters (Bielski and Johnson, 1972), releasing inorganic P for plant uptake (Tarafder and Junk, 1987).

\section{Nitrogen and phosphorus use efficiency}

Nitrogen use efficiency was significantly influenced by cover crop treatment and P X cover crops interaction was significant for $\mathrm{P}$ use efficiency (Table 14). The $\mathrm{P}$ use efficiency decreased with the increase in $\mathrm{P}$ rate, suggesting increase in root dry weight with the increase in $\mathrm{P}$ rates. Fageria (1992) reported that nutrient use efficiency decreased with the increase in nutrient rates in crop plants.

\section{CONCLUSIONS}

Cover crops play significant role in improving soil quality and consequently crop yields. Results of this study showed that $\mathrm{p}$ fertilization improved root growth of cover crops and increase in root growth varied with cover crop species. Maximum $\mathrm{P}$ rate which can be used in growing cover crop in the Brazilian Oxisols is $100 \mathrm{mg} \mathrm{P} \mathrm{kg}^{-1}$ soil. Uptake of $\mathrm{N}$ and $\mathrm{P}$ increased with the addition of $\mathrm{P}$ and this may be related to improvement in root growth of cover crops with the addition of P. Significant differences were also observed among cover crop species in uptake and use efficiency of $\mathrm{N}$ and $\mathrm{P}$ This 
may suggest selection and use of appropriate cover crop species is desirable to conserve nutrient losses and improve yield of economical crops in the cropping systems.

\section{REFERENCES}

Baligar, V. C., and N. K. Fageria, 2007. Agronomy and physiology of tropical cover crops. Journal of Plant Nutrition 30:1287-1339. http://dx.doi.org/10.1080/01904160701554997

Bieleski, R. L., and P. N. Johnson. 1992. The external location of phosphatase activity in phosphorus deficient Spirodela ologorrhiza. Australian Journal of Biological Science 25:707-720.

EMBRAPA. 1997. Manual of soil analysis methods, 2nd edition. Rio de Janeiro, Brazil: National Research Center of Soils.

Fageria, N. K. 1989. Tropical soils and physiological aspects of crops. EMBRAPA, Brasilia.

Fageria, N. K. 1992. Maximizing crop yields. New York: Marcel Dekker.

Fageria, N. K. 2007. Green manuring in crop production. Journal of Plant Nutrition. 5:691-719. http://dx.doi.org/10.1080/01904160701289529

Fageria, N. K. 2009. The use of nutrients in crop plants. Boca Raton, Florida: CRC Press.

Fageria, N. K. 2013. The role of plant roots in crop production. Boca Raton, Florida: CRC Press.

Fageria, N. K. and V. C. Baligar. 2008. Ameliorating soil acidity of tropical Oxisols by liming for sustainable crop production. Advances in Agronomy 99:345-399. http://dx.doi.org/10.1016/S00652113(08)00407-0

Fageria, N. K., V. C. Baligar, and B. A. Bailey. 2005. Role of cover crops in improving soil and row crop productivity. Communications in Soil Science and Plant Analysis 36:2733-2757. http://dx.doi.org/10.1080/00103620500303939

Fageria, N. K., V. C. Baligar and R. B. Clark. 2002. Micronutrients in crop production. Advances in Agronomy 77:185-268. http://dx.doi.org/10.1016/S0065-2113(02)77015-6

Fageria, N. K., V. C. Baligar, and R. B Clark. 2006. Physiology of crop production. New York: The Howorth Press.

Fageria, N. K., and A. Moreira. 2011. The role of mineral nutrition on root growth of crop plants. Advances in Agronomy 110:251-331. http://dx.doi.org/10.1016/B978-0-12-385531-2.00004-9

Fageria, N. K., and L. F. Stone. 2004. Yield of common bean in no-tillage system with application of lime and zinc. Pesquisa Agropecuaria Brasileira 39:73-78.

Gahoonia, T. S., and N. E. Nielsen. 2004. Root traits as tools for creating phosphorus efficient crop varieties. Plant Soil 260:47-57. http://dx.doi.org/10.1023/B:PLSO.0000030168.53340.bc

Hinsinger, P. 1998. How do plant roots acquire mineral nutrients? Chemical processes involved in the rhizosphere. Advances in Agronomy 64:225-265. http://dx.doi.org/10.1016/S0065-2113(08)60506$\underline{4}$

Marschner, H. 1995. Mineral nutrition of higher plants, 2nd edition. New York: Academic Press.

Silva, F. C. 1999. Manual of chemical analysis of soils, plants and fertilizers. Brasilia/Rio de Janeiro: Embrapa Communication and Transfer of Technology/Embrapa Soils.

Tarafder, J. C., and A. Jungk. 1987. Phosphatase activity in the rhizosphere and its relation to the depletion of organic phosphorus. Biology and Fertility of Soils. 3:199-204. http://dx.doi.org/10.1007/BF00640630 
Table 1. Root dry weight $\left(\mathrm{g} \mathrm{plant}^{-1}\right)$ of five tropical legume cover crops as influenced by phosphorus fertilization

\begin{tabular}{lccc}
\hline Cover crops & \multicolumn{3}{c}{ Phosphorus level $\left(\mathrm{mg} \mathrm{kg}^{-1}\right)$} \\
\cline { 2 - 4 } & $\begin{array}{c}\text { Low P } \\
\left(0 \mathrm{mg} \mathrm{kg}^{-1}\right)\end{array}$ & $\begin{array}{c}\text { Medium P } \\
\left(100 \mathrm{mg} \mathrm{kg}^{-1}\right)\end{array}$ & $\begin{array}{c}\text { High P } \\
\left(200 \mathrm{mg} \mathrm{kg}^{-1}\right)\end{array}$ \\
\hline Sunnhemp & $0.17 \mathrm{c}$ & $0.83 \mathrm{ab}$ & $0.64 \mathrm{c}$ \\
Pigeonpea & $0.16 \mathrm{c}$ & $0.51 \mathrm{~b}$ & $0.13 \mathrm{~d}$ \\
Lablab & $0.13 \mathrm{c}$ & $1.14 \mathrm{a}$ & $0.96 \mathrm{~b}$ \\
Gray mucuna bean & $0.53 \mathrm{~b}$ & $0.83 \mathrm{ab}$ & $1.42 \mathrm{a}$ \\
White jack bean & $0.77 \mathrm{a}$ & $1.12 \mathrm{a}$ & $0.93 \mathrm{~b}$ \\
\hline Average & $0.35 \mathrm{~b}$ & $0.89 \mathrm{a}$ & $0.82 \mathrm{a}$ \\
\hline F-Test & $* *$ & & \\
P level (P) & $* *$ & & \\
Cover crops (CC) & $* *$ & & \\
P X CC & & & \\
\hline
\end{tabular}

${ }^{* *}$ Significant at the $1 \%$ probability level. Means followed by the same letter in the same column are statistically not significant at the $5 \%$ probability level by Tukeys test. For comparison average values of P levels, same letter in the same li ne under different $\mathrm{P}$ levels are statistically not significant at the 5\% probability level by Turkeys test.

Table 2. Maximum root length $(\mathrm{cm})$ of five tropical legume cover crops as influenced by phosphorus fertilization

\begin{tabular}{lccc}
\hline Cover crops & \multicolumn{3}{c}{ Phosphorus level $\left(\mathrm{mg} \mathrm{kg}^{-1}\right)$} \\
\cline { 2 - 4 } & Low P & $\begin{array}{c}\text { Medium P } \\
\left(100 \mathrm{mg} \mathrm{kg}^{-1}\right)\end{array}$ & $\begin{array}{c}\text { High P } \\
\left(200 \mathrm{mg} \mathrm{kg}^{-1}\right)\end{array}$ \\
\hline Sunnhemp & $31.50 \mathrm{ab}$ & $24.50 \mathrm{~d}$ & $22.00 \mathrm{~b}$ \\
Pigeonpea & $21.33 \mathrm{bc}$ & $30.00 \mathrm{~cd}$ & $23.00 \mathrm{~b}$ \\
Lablab & $19.67 \mathrm{c}$ & $32.00 \mathrm{c}$ & $29.00 \mathrm{~b}$ \\
Gray mucuna bean & $31.50 \mathrm{abc}$ & $39.00 \mathrm{~b}$ & $51.00 \mathrm{a}$ \\
White jack bean & $36.00 \mathrm{a}$ & $50.33 \mathrm{a}$ & $52.33 \mathrm{a}$ \\
\hline Average & $27.40 \mathrm{~b}$ & $35.17 \mathrm{a}$ & $35.47 \mathrm{a}$ \\
\hline F-Test & $* *$ & & \\
P level (P) & $* *$ & & \\
Cover crops (CC) & $* *$ & & \\
P X CC & & & \\
\hline
\end{tabular}

${ }^{* *}$ Significant at the $1 \%$ probability level. Means followed by the same letter in the same column are statistically not significant at the $5 \%$ probability level by Turkeys test. For comparison average values of P levels, same letter in the same line under different $\mathrm{P}$ levels are statistically not significant at the 5\% probability level by Turkeys test.

Table 3. Nitrogen and $\mathrm{P}$ uptake $\left(\mathrm{mg} \mathrm{plant}^{-1}\right)$ in five tropical legume roots as influenced by $\mathrm{P}$ fertilization

\begin{tabular}{llllccc}
\hline Cover crops & \multicolumn{3}{c}{ P levels $\left(\mathrm{mg} \mathrm{kg}^{-1}\right)^{1}$} & \multicolumn{3}{c}{ P levels $\left(\mathrm{mg} \mathrm{kg}^{-1}\right)^{1}$} \\
\cline { 2 - 7 } & Low P & Medium P & High P & Low P & Medium P & High P \\
\hline Sunnhemp & $2.90 \mathrm{a}$ & $9.16 \mathrm{a}$ & $10.15 \mathrm{c}$ & $0.15 \mathrm{~b}$ & $0.84 \mathrm{a}$ & $0.72 \mathrm{c}$ \\
Pigeonpea & $6.92 \mathrm{a}$ & $6.63 \mathrm{a}$ & $2.09 \mathrm{~d}$ & $0.18 \mathrm{ab}$ & $0.42 \mathrm{a}$ & $0.18 \mathrm{c}$ \\
Lablab & $2.48 \mathrm{a}$ & $20.81 \mathrm{a}$ & $20.13 \mathrm{~b}$ & $0.11 \mathrm{~b}$ & $1.71 \mathrm{a}$ & $2.20 \mathrm{~b}$ \\
Gray mucuna bean & $12.79 \mathrm{a}$ & $21.90 \mathrm{a}$ & $37.14 \mathrm{a}$ & $0.44 \mathrm{a}$ & $0.99 \mathrm{a}$ & $3.33 \mathrm{a}$ \\
White jack bean & $13.96 \mathrm{a}$ & $18.67 \mathrm{a}$ & $20.15 \mathrm{~b}$ & $0.44 \mathrm{a}$ & $1.66 \mathrm{a}$ & $2.04 \mathrm{~b}$ \\
\hline Average & $7.81 \mathrm{~b}$ & $15.43 \mathrm{a}$ & $17.93 \mathrm{a}$ & $0.27 \mathrm{~b}$ & $1.12 \mathrm{a}$ & $1.69 \mathrm{a}$ \\
\hline F-Test & $* *$ & & $*$ & & \\
P level (P) & $* *$ & & $* *$ & & \\
Cover crops (CC) & $* *$ & & $* *$ & & & \\
P X CC & & & & & & \\
\hline
\end{tabular}

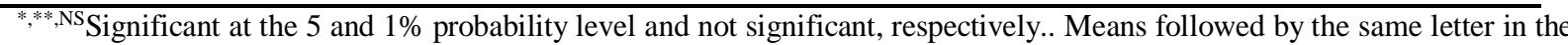
same column are statistically not significant at the 5\% probability level by Turkeys test. For comparison of means of P levels, same letter in the same line under different $\mathrm{P}$ levels are statistically not significant at the $5 \%$ probability level by Turkeys test.
} Low $\mathrm{P}=0 \mathrm{mg} \mathrm{P} \mathrm{kg}{ }^{-1}$; medium $\mathrm{P}=100 \mathrm{mg} \mathrm{P} \mathrm{kg}^{-1}$, and high $\mathrm{P}=200 \mathrm{mg} \mathrm{P} \mathrm{kg}^{-1}$. 
N. K. Fageria et al.

Table 4. Nitrogen and $\mathrm{P}$ use efficiency $\left(\mathrm{mg} \mathrm{mg}^{-1}\right)$ in roots of five tropical legume cover crops as influenced by $\mathrm{P}$ fertilization

\begin{tabular}{|c|c|c|c|c|}
\hline \multirow[t]{2}{*}{ Cover crops } & \multirow[t]{2}{*}{$\mathrm{N}\left(\mathrm{mg} \mathrm{mg}^{-1}\right)$} & \multicolumn{3}{|c|}{$\mathrm{P}\left(\mathrm{mg} \mathrm{kg}^{-1}\right)$} \\
\hline & & Low $\mathrm{P}^{1}$ & Medium $\mathrm{P}^{1}$ & High $\mathrm{P}^{1}$ \\
\hline Sunnhemp & $74.35 \mathrm{a}$ & $1119.75 \mathrm{ab}$ & $992.93 a$ & $910.03 \mathrm{a}$ \\
\hline Pigeonpea & $67.26 \mathrm{a}$ & $918.33 b$ & $1271.85 \mathrm{a}$ & $833.12 \mathrm{a}$ \\
\hline Lablab & $52.28 \mathrm{ab}$ & $1177.13 \mathrm{ab}$ & $837.26 a$ & $456.32 \mathrm{a}$ \\
\hline Gray mucuna bean & $40.46 b$ & $1215.08 \mathrm{ab}$ & $910.07 \mathrm{a}$ & $434.77 \mathrm{a}$ \\
\hline White jack bean & $54.66 \mathrm{ab}$ & $1960.67 \mathrm{a}$ & $702.86 a$ & $456.87 \mathrm{a}$ \\
\hline Average & 57.80 & $1278.19 \mathrm{a}$ & $942.99 \mathrm{ab}$ & $618.22 b$ \\
\hline \multicolumn{5}{|l|}{ F-Test } \\
\hline P level (P) & NS & $*$ & & \\
\hline Cover crops (CC) & $* *$ & NS & & \\
\hline $\mathrm{P} \times \mathrm{CC}$ & NS & $* *$ & & \\
\hline
\end{tabular}

${ }^{* * *, N S}$ Significant at the $1 \%$ probability level and not significant, respectively.. Means followed by the same letter in the same column are statistically not significant at the $5 \%$ probability level by Tukeys test. For comparison of means of P levels, same letter in the same line under different $\mathrm{P}$ levels are statistically not significant at the $5 \%$ probability level by Turkeys test. ${ }^{1}$ Low $\mathrm{P}=0 \mathrm{mg} \mathrm{P} \mathrm{kg}^{-1}$; medium $\mathrm{P}=100 \mathrm{mg} \mathrm{P} \mathrm{kg}^{-1}$, and high $\mathrm{P}=200 \mathrm{mg} \mathrm{P} \mathrm{kg}^{-1}$. 